\title{
The evolution of the institutional structure of the agricultural education in Russia
}

\author{
Olga Fedotova ${ }^{1, *}$, Vladimir Latun², Yuliya Merinova ${ }^{2}$, and Anna Ertel $^{2}$ \\ ${ }^{1}$ Don State Technical University, 1 Gagarin sq., 344003, Rostov on Don, Russia \\ ${ }^{2}$ Southern Federal University, 105/42, B. Sadovaya Str., 344006, Rostov on Don, Russia
}

\begin{abstract}
The article is devoted to the analysis of the history of the formation of agricultural education in Russia. On the basis of the analysis of historical data, documents on creation of educational institutions and statistical data dynamics of emergence of new agricultural lowest schools, secondary schools, academies and institutes is established. It is shown that the first agricultural institutions were established in the 18th century with the participation of the great Russian scientist M. Lomonosov with the support of the Emperor. The first agricultural schools used foreign experience. A total of three agricultural schools were established. However, in the future there was a transition to training without the participation of foreigners. An analysis of the development of the education system in the 19th century found that the institutional structure changed significantly towards the emergence of institutions and academies. Model farms, model estates and new training areas have appeared personnel for horticulture, agronomists, beekeepers, horse breeders, etc. Private initiatives have facilitated the opening of new specialties. The state opened new specialized academies and faculties in polytechnic institutes. It is shown that traditions of improving the institutional system of training of personnel persist in modern Russia.
\end{abstract}

\section{Introduction}

Agriculture is the most important sector of the economy, guaranteeing the sovereignty and prosperity of the country and ensuring a decent life for citizens. The formation and development of a training system for agriculture has a long tradition worldwide $[1,2,3,4$, 5]. In Russia, these traditions are also old, but little studied $[6,7,8,9]$. The ability of a person to grow plants, raise livestock, use available natural resources to ensure his life was a combination of knowledge and skills, based on observation of nature and analysis of practical experience transmitted from generation to generation.

The study of the institutional organization of the structure of education to meet the needs of the agronomic business, the identification of vectors and mechanisms for the transformation of relevant institutions, the progress and consequences of institutional reforms, the internal structure and the influence of external institutions on the reform of

\footnotetext{
*Corresponding author: fod1953@yandex.ru
} 
agricultural enterprises and education are currently attracting special attention of researchers $[10,11,12,13]$.

The basis of the evolutionary study of the institutional structure of the agro-industrial sphere of the economy is the classification of historical periods of development of institutions of education and institutions of agriculture economy of Russia within the chronological framework, presented in the works of V.P. Frolov [14]. The author gave a systematic analysis of the evolution of the institutional structure of the Russian agroindustrial complex as a complex historical process of changing institutions and mechanisms. He identified various stages of agricultural education formations. At the same time, the counting of the development of the agricultural education system from starts only from 1861 .

Problems of agricultural education history were not the focus of scientific interests of researchers from Russia. In 1959, the analysis of the employment of peasants from the noble properties of Moscow region in the 18th century was considered by S.I. Volkov [15]. The same topic was continued in the study of N.M. Druzhinin [16]. In this study, State peasants are the subject of analysis. Foreign researchers are mainly interested in modern problems of young people who have received agricultural education. At the same time, they note that young specialists do not want to work in rural areas [17]. Issues of improvement of quality of education are considered by Z. Kapsdorferova and O. Sviridova [18]. They advocate improving the quality of agricultural education by taking into account uniform requirements from the Agriculture Employers Union.

Thus, the problem is that Russian and foreign researchers and organizers of agricultural education are not aware of the institutional foundations of its historical development, which have determined the modern state of agricultural education.

\section{Methodology}

The purpose of the study is to determine the sequence and features of the formation of the system of agricultural education in Russia from the time of its inception to the end of the imperial period of development (until the Soviet era).

The empirical array is the texts of government documents (orders, directions, reports) on the opening or approval of training regulations in the system of agricultural institutions at various levels and statistical data. They are systematically presented in the Journal of the Ministry of Education, which is a reliable source of information about the development of the educational system in pre-revolutionary Russia [19].

Research methods - the retrospective method, content analysis, interpretation, the comparative analysis, generalization, comparison [20,21]. When carrying out a content analytical research the semantic category of the analysis and a tally will be in detail described within each stage. For graphic design of the results the EXCEL program was used.

The research was carried out in two steps.

\section{Results}

The first investigation phase is designed to determine the chronological sequence of the emergence of educational institutions in which training for agriculture was carried out.

Historical sources show that training began in the 18 century. In the first half of the 18 th century, the first stable schools were organized. The very first such school was organized by Count F.E. Angalt at the horse factory in 1735 in the village of Khoroshevo. The development of agricultural education as a separate educational industry was started by $\mathrm{M}$. 
V. Lomonosov, on the initiative of which in 1765 farming classes were organized in the Russian Academy of Sciences.

The government initiative to create a practical school of farming belongs to Emperor Paul I. In 1797, the first special educational institution for training personnel for agriculture was founded near St. Petersburg. Its task was to train specialists acting as a mentor on socalled "model farms." These farms were to become the flagship of agricultural production through the use of the most advanced foreign and domestic agricultural experience. A feature of the approach to the organization of training was the fact that best foreign experience should not have been broadcast by foreigners. Russian teachers-mentors who know traditions, customs, climatic conditions, take into account the existing effective experience in the field of livestock and crop production should teach. An unpopular measure was taken to form a corps of learners who were to become mentors. Selected young treasury peasants who showed smack and learning abilities were recruited for training. This did not add to the popularity of this educational institution, which after six years of its existence, in 1803, was closed. In total, three professional schools were established in the 18th century, which did not meet the country 's staffing needs.

The second stage of the study is devoted to the analysis of the development of agricultural education in the 19th century. At this time, there has been a significant increase in educational institutions for agriculture. The calculation of their number by different levels of educational institutions is shown in Figure 1.

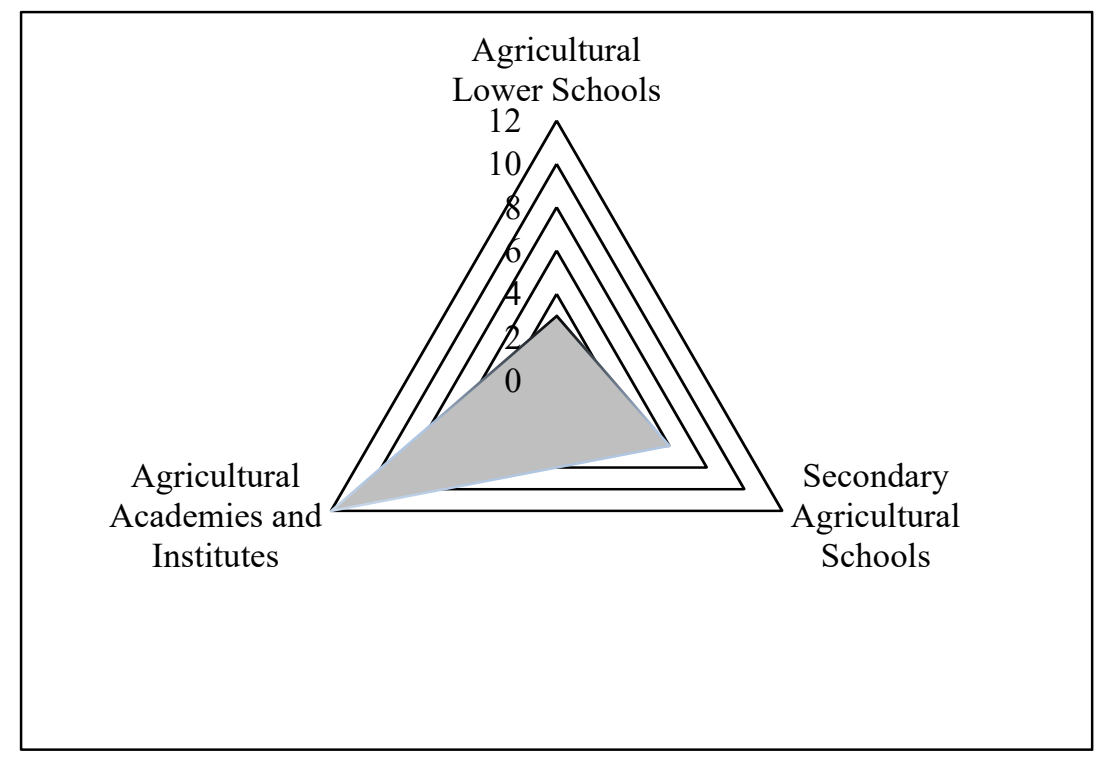

Fig. 1. Number of educational institutions for agriculture in the 19th century (by education level).

As shown in the figure, the number of institutions of different types persuades us that secondary and higher-level training institutions prevail. They are directly related to changes in the country 's economic needs. An important step in the establishment of the agricultural education system is the opening in 1822 of a special school for the training of sales, office employees and clerks, whose activities were closely related to the organizational and economic support of agriculture.

At this school, which was opened thanks to the efforts of the Moscow Society of Agriculture, the "model" (experimental) farm "Butyrsky hutor" was constantly working. According to the documents of that time, the initiators of the opening of agricultural educational institutions of the lower order were not only voluntary societies, which unite 
enthusiasts, but also landlords interested in the efficient conduct of agriculture. In their estates on their funds experimental-model gardens, farms, apiaries, wine cellars were created. Graduates of primary private agricultural schools could hold positions of agronomic chiefs, assistants of agronomists, accounting officers, i.e. employees of lower management level.

The first secondary agricultural school in Russia was founded in 1835 on the basis of the lower agricultural school of the Moscow Society of Agriculture. In the following decades, about 20 secondary agricultural schools were established. According to their profile, they were divided into common agricultural, horticulture and farming, viticulture and winemaking, land and agronomy, agricultural and hydrotechnician, etc. Graduates of schools received qualification of agronomist, gardener, winemaker, land maker, hydrotechnician, crops-equipment and worked as district and county agronomists, land managers, foresters, managers of estates, teachers of lower agricultural educational institutions. In hydrotechnical and some other agricultural schools (Gory-Goretsk and Kovenskiy) the term of study was 4 years, in the rest -6 years. The agricultural education system gained some stability by 1904 , turning to mass training, which was to ensure the development of the system of production of agricultural products, demanded not only in the territory of the Russian Empire, but also abroad.

At that time, the main task of improving farming methods was to develop crop production, create artificial meadows for livestock production. The students worked on training farms, at the end of which they were sent to specially organized "model estates" in voles and villages, which were an example of improved farming. However, practical methods of education caused the peasants mistrust, the school lasted only 5 years. Another problem with the development of agricultural education during this period was the institutional discrepancy. The school was subordinate to two departments: the Expeditions of the State Economy and the Ministry of Health, and each of them determined the results of the schools in different ways, were insufficiently financed, had a large departmental bureaucracy.

Changes in the economy of the country at the beginning of the 19th century defined the foundation for the development of agricultural education. In 1802-1807, schools of wine production were established in the Caucasus, Kizlyar, Akkerman, as well as a school of horticulture in the Nikit Botanical Garden (in Crimea). In 1822 the Moscow Farming School was opened, and in 1825 on the initiative of Countess S.V. Strohanova the farming school in St. Petersburg was opened. At this time, a school of farming for serf peasants was opened in Novgorod Province. During this period, separate agricultural courses and schools were established. Since the mid-1930s, the state 's approaches to agricultural education have adopted a more systemic vector as a result of P.D. Kiselev 's reforms.

The analysis of the experience gained identified the "policy of guardianship" as a way of developing agricultural education aimed at progressive changes in the Russian village. The Ministry of State Property divided all educational institutions into three categories: higher, middle and lower. During this period special (1-2 years) agricultural schools were established to train gardeners, winemakers, pastoralists and lower agricultural schools (3 years), training assistant agronomists. The third category was represented by training farms designed to teach the children of state peasants. Prior to the abolition of serf law in Russia in 1861, there were 8 such farms. The Department of Agriculture and the Ministry of Public Education supervised both public and private educational institutions. The first secondary institution was founded in 1835 on the basis of the lower agricultural school Moscow Farming School. However, such institutional changes have not had a significant impact on the development of the agricultural sector. The main composition of the Russian peasant was hardly affected by the measures to improve the agricultural sector. By the middle of the 19th century, Russia was markedly inferior to other countries in the field of agricultural 
education, as educational programs could solve issues of basic literacy and rational management skills, but were not aimed at solving topical issues of effective land management. Thus, the experience of establishing the first agricultural training institutions on the basis of private initiative without organizational, legal and substantial financial support from the State did not contribute to their effective functioning.

From 1861 to 1916 the agricultural education system developed in the process of accumulation of institutional contradictions in the agrarian sphere against the background of formation and strengthening of economic institutions. There is an objective need for skilled workers in the agricultural sector. During this period, education in agriculture was carried out by public bodies under the direction of the Department of Farming. Educational organizations were also established under the management of Earth administrations, cooperative organizations and individual large landlords. The network of higher, secondary and lower agricultural educational institutions in pre-revolutionary Russia has developed extremely slowly. Agricultural schools were divided into two categories: general agriculture and special (horticulture, gardening, winemaking, etc.).

The network of lower schools arose, as in earlier periods, at the initiative of the lands and individuals, so the founders themselves chose the programs of education without coordination, defining the main task for their development to increase the productivity and efficiency of specific farms. During this period, agricultural higher education institutions appeared in the Russian Empire. The Petrovsk Farming and Forestry Academy was established on December 3, 1865, and the Moscow Agricultural Institute was opened in 1894. Institutes and secondary agricultural schools trained agronomists, land managers, veterinary doctors, foresters and surveyors, and lower schools and schools trained technicians and junior specialists (field farmers, gardeners, horse farmers, etc.). Short-term higher agricultural courses trained livestock control assistants, junior veterinary paramedics, land managers, foresters, forest workers, beekeepers, specialist in water supply, etc.

Despite a limited network of educational institutions, agricultural education in Russia played a progressive role in the development of domestic agricultural science. In this regard, outstanding scientists - professors of higher educational institutions D. I. Mendeleev, A. V. Soviets, K. A. Timiryazev, P. A. Kostychev, V. V. Dokuchayev carried out particularly important work. A. N. Engelhardt, I. A. Stebut, V. R. Williams, P. S. Kossovich, D. N. Skepnishnikov, N. P. Chirvinsky, E. A. Bogdanov, M. F. Ivanov, P. N. Kuleshov, etc. The Russian people are proud of the names of these scientists. The works of these scientists have created and developed the most important branches of agricultural knowledge.

\section{Conclusion}

As the analysis of the dynamics of the formation of the institutional structure of education for the agricultural complex showed, in the 19th century there were significant changes. General trends reflect the State 's desire for training, which has been in demand for the rapid development of agriculture. The list of higher institutions with professional training has been expanded. Specialized higher education institutions - veterinary, farming, land and forestry institutes, as well as faculties in polytechnic institutes - have emerged. They gave both deep theoretical and practical training.

The modern education system, being on the path of reforms of all its levels, in addition to solving internal methodological and theoretical problems, traditionally develops variability and orientation to solve practical tasks in training personnel for the economy, including specialists of the agro-industrial sector. The study of the institutional organization of the structure of education to meet the needs of agribusiness, the identification of vectors 
and mechanisms for the transformation of relevant institutions, the progress and consequences of institutional reforms, the internal structure and the influence of external institutions on the reform of agricultural enterprises are of particular interest to researchers. As a result of the implementation of the priority national project "Development of the agroindustrial complex," innovative production technologies and modern machine systems are being intensively introduced and used effectively in all sectors of the agro-industrial complex.

Thus, the main direction of agricultural education development becomes its compliance with the requirements of the modern market, which is able to prepare qualitatively new personnel, who have perfect knowledge of methods and technologies in production.

\section{References}

1. M. Saadvandi, E. Abbasi, H. Farhadian, Journal of agricultural education \& extension 25(4), 307-322 (2019)

2. K. Davis, Journal of agricultural education \& extension 25(3), 193-194 (2019)

3. J. Deming, A. Macken-Walsh, B. O'Brien, Journal of agricultural education \& extension 25(1), 63-78 (2019)

4. A.J. Turner, Historical records of Australian science 30(1), 63-64 (2019)

5. M. Khorrami, H. Farhadian, E. Abbasi, Journal of global entrepreneurship research. 8(1), 63-64 (2018)

6. V. Prisacaru, A. Caradja, Scientific papers-series management economic engineering in agriculture and rural development 19(1), 485-490 (2019)

7. S.V. Stankevych, M.D. Yevtushenko, V. Zabrodina, Ukrainian journal of ecology 9(2), 170-178 (2019)

8. M. Biliavskii, E. Petrov, I. Muntian. Science and education 4, 10-17 (2015)

9. E. Platonova, M. Mysarskiy, O. Fedotova et al., EDULEARN Proceedings, 4555-4564 (2016)

10. J. Priscila Cian, Mundo agrario 19(42), 309-324 (2018)

11. D.G. Duarte da Silva, L.H. da Silva. Revista Brasileira de educacao do campo 3(3), 890-909 (2018)

12. M. Peden, Journal of education 60, 63-99 (2015)

13. Y. Aballe-Rosales, Y. Perez-Borrego, LUZ 18 (4), 99-109 (2019)

14. D.P. Frolov, Questions of regulation of economy 6(4), 79-93 (2015)

15. S.I. Volkov, Peasants of palace properties of Moscow region in the middle (30 1970s) (Moscow, 1959)

16. N.M. Druzhinin, State peasants and P.D. Kiselev 's reform (Moscow, 1958)

17. 1. Unay-Gailhard, M. Bavorova, Z. Bednarikova. Rural sociology 84(2), 315349 (2019).

18. Z. Kapsdorferova, O. Sviridova, International Scientific Days (ISD) Conference on Agri Food Value Chain (2016)

19. O. Fedotova, Procedia - Social and Behavioral Sciences 214, 414 - 420 (2015)

20. R.K. Bhardwaj, Desidoc journal of library \& Information technology 39(6), 280-289 (2019).

21. W.W. Xuan, S. Chen. Word-Journal of the international linguistic association 65(4), 213-233 (2019) 